\title{
PENANAMAN MODAL DAN PERTUMBUHAN EKONOMI TINGKAT PROVINSI DI INDONESIA
}

\author{
Rahma Dian Hapsari \\ Fakultas Ekonomi, Universitas Indonesia Jakarta \\ rahmadhapsari@gmail.com \\ Imam Prakoso \\ Fakultas Ekonomi, Universitas Indonesia Jakarta \\ imamprakoso90@ymail.com
}

\begin{abstract}
This research examines the impact whether foreign direct investment (PMA) can significantly influence the gross domestic regional product (PDRB) and how moderation variable of Unemployment Rate (TPT) and Human Development Index (IPM) also influence to Indonesian provinces as the research objects of this study. The data was taken from 2004-2013 (10 years). By using General Methods of Moments (GMM), this research shows PMA does not have any impact on economic growth. On the other hand, domestic direct investment (PMDN) is able to increase economic growth. This implies that PMA only funded the needs to less strategic investment sector. To boost up evenly the provincial economic growth, government should increase the incentive on investment to attract foreign investors to invest on less strategic sectors, and create incentive for domestic investors to maintain the business. Another conclusion is Indonesian workers are not developed due to the presence of $P M A$, and it indicates that there is no transfer of technology. Government needs to maintain PMDN and attract investors to invest in other sectors that are still not efficiently managed by PMDN.
\end{abstract}

Keywords: economic growth in province, foreign direct investment, strategic investment

\begin{abstract}
ABSTRAK
Penelitian ini menguji dampak Penanaman Modal Asing (PMA) terhadap Pendapatan Daerah Regional Bruto (PDRB) dan bagaimanakah pengaruh hubungan moderasi yang lain Tingkat Pengangguran Terbuka (TPT) dan Indeks Pembangunan Manusia(IPM) dengan menggunakan provinsi-provinsi di Indonesia sebagai objek penelitian dari tahun 2004-2013 (10 tahun). Dengan menggunakan General Methods of Moments (GMM), penelitian ini membuktikan bahwa PMA tidak mampu meningkatkan pertumbuhan ekonomi. Sebaliknya, penanaman modal dalam negeri (PMDN) mampu meningkatkan pertumbuhan ekonomi. Hal ini dikarenakan PMA hanya mengisi kebutuhan dana atas sektor yang kurang strategis. Untuk meningkatkan pertumbuhan perekonomian provinsi secara merata pemerintah perlu meningkatkan insentif investasi untuk menarik investor asing berinvestasi pada sektor yang kurang strategis dengan mengupayakan insentif lain bagi investor dalam negeri untuk mempertahankan
\end{abstract}


usahanya. Kesimpulan lainnya adalah pekerja di Indonesia tidak berkembang dengan adanya PMA, artinya tidak terjadi transfer teknologi. Pemerintah perlu mempertahankan PMDN dan menarik investor untuk berinvestasi dalam sektor yang masih belum efisien dikelola oleh PMDN.

Kata kunci: pertumbuhan ekonomi provinsi, penanaman modal asing, investasi strategis

\section{PENDAHULUAN}

Dari tahun ke tahun, pemerintah berusaha mengeluarkan paket investasi yang mampu menarik minat investor melalui pengurangan biaya perusahaan melalui perpajakan atau kemudahan lainnya (contohnya: No.144/PMK.011/2012 dan No.76/PMK.011/2012). Investasi di suatu negara dapat bersumber dari investasi dalam negeri maupun investasi asing. Penanaman Modal Dalam Negeri (PMDN) maupun Penanaman Modal Asing (PMA) yang tepat sasaran akan sama-sama meningkatkan perekonomian bangsa. Investasi tersebut dapat berbentuk investasi langsung yakni berupa pembelian aset atau pembentukan usaha baru maupun investasi tidak langsung yakni berupa investasi di pasar uang dan pasar modal.

Peran PMA pada suatu perekonomian negara akan menentukan perekonomian tersebut. Apabila PMA hanya sebagai tambahan modal untuk memenuhi kebutuhan yang tidak dapat ditutupi oleh PMDN, maka PMA hanya akan berdampak pada jangka pendek. Hal tersebut dikarenakan peran penting PMA dalam mentransfer aset akan semakin efisien. Sebaliknya, PMA dapat membawa inovasi kepada negara tuan rumah sehingga dapat mendorong perekonomian melalui kegiatan usaha yang lebih efisien dan efektif. Peningkatan ekonomi melalui pembelajaran teknologi asing dan cara lainnya tidak terlalu efektif pada negara berkembang karena memiliki tingkat pendidikan yang kurang (Li \& Liu 2005). Penelitian masih banyak yang masih pro dan kontra, menjadikan fenomena tersebut masih menarik untuk diuji terlebih dengan menggunakan sampel yang lebih spesifik yaitu provinsi-provinsi di Indonesia.

Investasi yang dilakukan asing dapat secara langsung memengaruhi jumlah permodalan, meningkatkan kualitas SDM dan memajukan perkembangan teknologi pada negara yang dituju (De Mello 1999). Namun, PMA hanya dapat meningkatkan output dalam jangka pendek dan membatasi pertumbuhan ekonomi dalam jangka panjang karena return atas modal asing tersebut akan mengalami penurunan dalam jangka panjang (diminishing marginal productivity of capital) jika tidak terdapat inovasi yang berarti. Hal ini mengakibatkan pengaruh PMA terhadap perekonomian akan bervariasi, tergantung pada kondisi tertentu. Penelitian sebelumnya menemukan bahwa PMA dapat meningkatkan pertumbuhan ekonomi regional di Indonesia (Latip 2009), peran PMA menentukan keefektifan pengaruhnya terhadap pertumbuhan ekonomi. Penelitian lainnya membuktikan tidak ada peningkatan produktivitas yang signifikan antara perusahaan yang diakuisisi oleh pihak asing atau domestik di Cina 
sehingga transfer teknologi belum tentu berjalan dengan baik (Wang dan Wang 2015). Bertolak dari hasil-hasil penelitian yang masih bervariasi, maka penelitian ini dapat memberikan gambaran baru terhadap literatur ilmiah.

PMA tidak mampu meningkatkan pertumbuhan perekonomian karena pemerintah Indonesia memprioritaskan sektor strategis untuk dikelola dengan menggunakan PMDN. Hal ini diperkuat dengan kemampuan PMDN dalam meningkatkan perekonomian provinsi. Pemerintah perlu untuk mempertahankan PMDN dibandingkan PMA untuk meningkatkan perekonomian di setiap provinsi sehingga perekonomian Indonesia menjadi lebih merata. Dengan membandingkan hasil kesimpulan penelitian ini, serta penelitian Wang dan Wang (2015) terkait dampak akuisisi oleh pihak asing, PMA belum teruji dalam meningkatkan perekonomian disetiap propinsi. Pemerintah perlu mempertahankan strategi investasi untuk menarik investor asing namun mendorong mereka untuk berinvestasi di sektor yang belum mampu diolah oleh pihak dalam negeri.

Tidak seperti banyak penelitian sebelumnya, Indeks Pembangunan Manusia (IPM) tidak mampu berpengaruh terhadap perekonomian provinsi karena IPM di Indonesia tidak terlalu tinggi dibandingkan negara lainnya. Dengan demikian, pekerja di Indonesia tidak berkembang atau tidak terjadi transfer teknologi yang optimal. Penelitian ini juga memberikan pandangan baru bagi literatur bahwa dalam skala yurisdiksi yang lebih kecil (provinsi), PMA belum tentu mampu meningkatkan perekonomian negara. Selain itu dalam kondisi yang sama, pertumbuhan perekonomian sebelumnya tidak berpengaruh terhadap perekonomian masa sekarang karena tidak adanya trade barrier pada tingkat provinsi.

Pada tahun 2001, pemerintah Indonesia melakukan kegiatan otonomi daerah. Pengujian dengan menggunakan tahun setelah otonomi daerah akan menarik karena kebijakan dan kondisi daerah memegang peranan penting dalam keefektifan PMA karena hanya terkonsentrasi pada wilayah Jabodetabek, Jawa Barat dan Papua. Pemerintah daerah diharapkan mampu untuk dapat mandiri dalam membangun daerahnya dan menggunakan PMA dan PMDN dengan efisien. Pertanyaan penelitian ini adalah apakah Penanaman Modal Asing (PMA) dapat berpengaruh signifikan terhadap Pendapatan Daerah Regional Bruto (PDRB) dan bagaimanakah pengaruh hubungan moderasi yang lain Tingkat Pengangguran Terbuka (TPT) dan Indeks Pembangunan Manusia (IPM)?

Manfaat dari penelitian ini adalah untuk menambah pandangan baru terhadap literatur terkait, dan dapat memberikan masukan bagi pemerintah dalam melakukan perencanaan ekonomi domestik. Selanjutnya hasil dari penelitian ini diharapkan dapat membantu pemerintah tingkat provinsi sebagai bahan evaluasi. 


\section{KAJIAN PUSTAKA DAN PERUMUSAN HIPOTESIS}

\section{Arus Kas Asing dan Produk Domestik Regional Bruto}

Investasi yang saat ini sedang ditingkatkan oleh negara-negara berkembang adalah dalam bentuk PMA. Menurut undang-undang Republik Indonesia No. 25 tahun 2007 tentang Penanaman Modal, PMA adalah kegiatan menanam modal untuk melakukan usaha di wilayah negara Republik Indonesia yang dilakukan oleh penanam modal asing, baik yang menggunakan modal asing sepenuhnya maupun yang berpatungan dengan penanam modal dalam negeri. PMA yang didefinisikan oleh Badan Koordinasi Penanaman Modal (BKPM) mencakup modal asing langsung (foreign direct investment/FDI) yang didaftarkan pada BKPM. Investasi yang didaftarkan pada BKPM akan diakui negara dan memiliki nilai yang relatif besar.

Data Badan Koordinasi Penanaman Modal menunjukkan pada tahun 1998, PMA mengalami peningkatan yang cukup signifikan yaitu senilai 10 Miliar USD dengan 416 proyek. Hal ini dikarenakan pelemahan nilai tukar rupiah setelah krisis moneter di Indonesia. PMA terus meningkat dalam beberapa tahun terakhir. Pola yang berbeda tampak pada penanaman modal dalam negeri (PMDN), yang mengalami peningkatan pesat saat tahun 1996 senilai Rp18 triliun dengan jumlah proyek 453. Namun nilai PMDN terus menurun sampai tahun 1999 krisis, dan terus mengalami fluktuasi sampai dengan diterapkannya otonomi daerah tahun 2001. Setelah tahun 2001, PMDN mengalami peningkatan tiap tahunnya sampai pada tahun 2006 yang mengalami penurunan. Kemudian pada tahun tahun 2007 kembali naik menjadi senilai Rp34 triliun dengan jumlah proyek 164 proyek. Tahun 2008 PMDN mengalami penurunan kembali akibat krisis. Fluktuasi tersebut rendah karena dipengaruhi oleh sentimen investasi di Indonesia yang rendah dalam ketidakpastian ekonomi.

Arus permodalan yang efektif dapat memajukan perusahaan sehingga meningkatkan laju perekonomian pada suatu daerah. Sebagai contoh, perekonomian di Kabupaten Kolaka (Sulawesi Tenggara) memiliki kemajuan ekonomi yang pesat setelah beroperasinya Unit Metalurgi milik PT Aneka Tambang (Persero) Tbk. Peningkatan modal baik dalam bentuk PMDN dan PMA mampu meningkatkan potensi daerah dan perkembangan manusia di Indonesia melalui pembelajaran ataupun penyerapan teknologi asing yang lebih maju. Namun, Li dan Liu (2005) menemukan bahwa pembelajaran tersebut tidak terlalu efektif pada negara berkembang karena memiliki tingkat pendidikan yang kurang.

Penelitan yang dilakukan De Mello (1999) berkesimpulan bahwa PMA dapat secara langsung memengaruhi jumlah permodalan, meningkatkan kualitas SDM dan memajukan perkembangan teknologi pada negara yang dituju. Dengan meningkatnya produktifitas dan pengembangan teknologi yang efektif akibat PMA maka perekonomian daerah-daerah di Indonesia akan meningkat. Ostry et al. (2010) menyatakan bahwa meskipun manfaat yang diterima cukup besar, besarnya arus asing dapat merupakan aksi investor yang melindungi nilai investasinya sehingga bersifat 
sementara dan dapat memengaruhi tingkat suku bunga. Sehingga PMA kemungkinan besar akan meningkatkan output dalam jangka pendek dan membatasi pertumbuhan ekonomi dalam jangka panjang karena sensitif terhadap tingkat suku bunga dan terjadi penurunan produktifitas modal dalam jangka panjang (diminishing marginal productivity of capital).

Banyak penelitian sebelumnya yang membuktikan hubungan positif antara arus asing dan pertumbuhan (Adams \& Opoku 2015). Namun hubungan tersebut dapat bervariasi pada kondisi tertentu. Ada hubungan positif terhadap pertumbuhan ekonomi pada 100 negara (Aizenman, Jinjarak, \& Park 2013). Pengaruh PMA terhadap pertumbuhan ekonomi dapat bergantung pada kondisi perekonomian dunia pada waktu tertentu (Gui-Diby 2014). Pada periode sebelum 1994, PMA memiliki hubungan negatif terhadap perekonomian negara-negara di Afrika sedangkan pada tahun sesudahnya hubungan tersebut menjadi positif. Tahun 1994-2012 pada studi lintas negara menemukan bahwa secara umum arus modal asing dapat meningkatkan pertumbuhan ekonomi namun masih terdapat kondisi-kondisi yang membuat hubungan tersebut tidak berlaku (Almfraji \& Almsafir 2014).

Di Indonesia, PMA dibuktikan dapat meningkatkan pertumbuhan ekonomi provinsi (Latip 2009). Berbeda dengan penelitian tersebut, penelitian ini menggunakan rentang waktu yang panjang (10 tahun) dan mengkontrol variabel dependen dengan lagged value. Selain itu, karena setiap negara akan melindungi kepentingan warga negaranya sehingga PMA belum tentu memiliki pengembalian investasi yang besar karena diutamakan untuk investasi yang tidak sanggup dimodali melalui PMDN (PMK no.144/PMK.011/2012). Pernyataan itu dibuktikan dengan penelitian yang dilakukan (Feeny, Iamsiraroj, \& McGillivray 2014) bahwa di negara kepulauan pasifik dimana peluang investasi asing sangat kecil, terbukti tidak mampu mendongkrak pertumbuhan ekonomi. Penelitian lainnya membuktikan tidak ada peningkatan produktifitas yang signifikan antara perusahaan yang diakuisisi oleh pihak asing atau domestik di Cina sehingga transfer teknologi belum tentu berjalan dengan baik (Wang \& Wang 2015). Disisi lain, dalam jangka panjang modal tersebut akan mengalami penurunan produktivitas, sehingga investasi asing langsung dan tidak langsung akan memiliki dampak yang serupa. Dengan demikian pengujian apakah PMA dapat meningkatkan perekonomian provinsi masih menarik untuk dilakukan.

\section{Perumusan Hipotesis}

Penelitian ini menggunakan tingkat tenaga kerja karena memiliki dampak positif terhadap pertumbuhan ekonomi sebagai input dalam menciptakan barang produksi. Variabel TPT sebagai variabel moderasi akan melemahkan hubungan antara PMA dan PDRB. Variabel moderasi lain yang digunakan pada penelitian ini adalah IPM. Hal ini dikarenakan peningkatan pertumbuhan tersebut sangat bergantung kepada produktifitas pekerja bukan jenis investor (Wang \& Wang 2015). Penelitian ini menggunakan variabel PMDN untuk mengganti variabel PMA agar dapat memberikan 
bukti yang lebih beragam. Berdasarkan argumentasi dan riset terdahulu, dapat dirumuskan hipotesis sebagai berikut.

H1: PMA memiliki pengaruh positif terhadap PDRB.

H2: Tingkat Pengangguran Terbuka memiliki pengaruh negatif terhadap hubungan PMA dan PDRB.

H3: Indeks Pembangunan Manusia memiliki pengaruh positif terhadap hubungan PMA dan PDRB.

Model penelitian disajikan pada Gambar 1 berikut.

Keterangan :

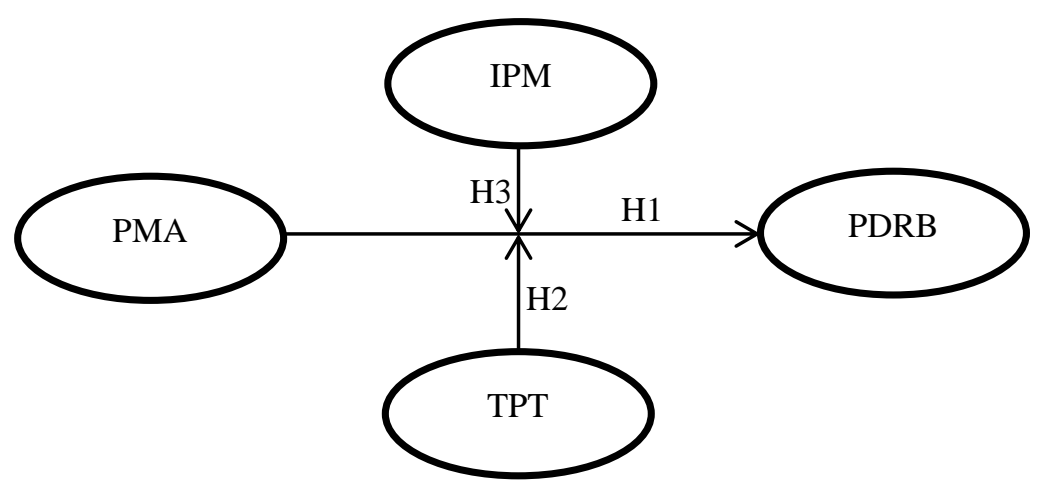

PMA = Penanaman Modal Asing

IPM = Indeks Pembangunan Manusia

PDRB = Produk Domestik Regional Bruto

TPT = Tingkat Pengangguran Terbuka

\section{Gambar 1 \\ Model Penelitian}

\section{METODA PENELITIAN}

\section{Sampel dan Data Penelitian}

Penelitian ini menggunakan data yang bersumber dari Badan Pusat Statistik (BPS) dan Badan Koordinasi Penanaman Modal (BKPM) dengan rentang waktu observasi 2004-2013 (10 tahun). Provinsi baru yaitu Sulawesi Barat menggunakan data provinsi sebelum pemekaran yaitu Sulawesi Selatan. Penelitian belum menggunakan provinsi Kalimantan Utara sebagai sampel karena data pada BPS belum menyediakan data untuk provinsi tersebut. Jumlah observasi pada seluruh variabel berjumlah 330 sampel.

\section{Model Penelitian}

Dengan menggunakan provinsi-provinsi di Indonesia sebagai sampel, penelitian ini mengestimasi dan menjawab hipotesis penelitian dengan menggunakan model penelitian umum (Model 1) dengan beberapa model lain sebagai robustness test. Robustness test dilakukan dengan menggunakan variabel moderasi TPT dan IPM 
dan mengganti variabel PMA dengan PMDN. Definisi variabel penelitian dapat dilihat pada Tabel 1.

Tabel 1

Definisi Variabel

\begin{tabular}{|c|c|}
\hline $\begin{array}{c}\text { Nama } \\
\text { Variabel }\end{array}$ & Definisi \\
\hline PDRB & $\begin{array}{l}\text { Produk Domestik Regional Bruto. Pertumbuhan nilai tambah (nilai } \\
\text { produksi (output) dikurangi biaya antara) yang timbul dari seluruh } \\
\text { sektor perekonomian (termasuk migas) pada suatu provinsi. }\end{array}$ \\
\hline PMA & $\begin{array}{l}\text { Arus Penanaman Modal Asing. Arus modal asing yang digunakan } \\
\text { untuk investasi pada kegiatan yang dikategorikan sebagai penanaman } \\
\text { modal asing. Nilai PMA disajikan dalam nilai logaritma natural. }\end{array}$ \\
\hline PMDN & $\begin{array}{l}\text { Penanaman Modal Dalam Negeri. Arus modal dalam negeri diukur } \\
\text { dengan jumlah arus modal dalam negeri yang digunakan untuk } \\
\text { investasi pada kegiatan usaha di dalam negeri }\end{array}$ \\
\hline INF & $\begin{array}{l}\text { Indeks Harga Konsumen. Indeks yang menghitung rata-rata } \\
\text { perubahan harga dalam suatu periode, dari suatu kumpulan barang dan } \\
\text { jasa yang dikonsumsi oleh penduduk/rumah tangga dalam kurun waktu } \\
\text { tertentu. }\end{array}$ \\
\hline IPM & $\begin{array}{l}\text { Indeks Pembangunan Manusia. Indeks yang mengukur capaian } \\
\text { pembangunan manusia berbasis sejumlah komponen dasar kualitas } \\
\text { hidup dengan dimensi seperti umur panjang dan sehat, pengetahuan, } \\
\text { dan kehidupan yang layak. }\end{array}$ \\
\hline TPT & $\begin{array}{l}\text { Tingkat Pengangguran Terbuka. Tenaga kerja yang sungguh- } \\
\text { sungguh tidak mempunyai pekerjaan karena memang belum mendapat } \\
\text { pekerjaan padahal telah berusaha secara maksimal. }\end{array}$ \\
\hline APK & $\begin{array}{l}\text { Angka Partisipasi Kasar. Proporsi anak sekolah pada suatu jenjang } \\
\text { tertentu dalam kelompok usia yang sesuai dengan jenjang pendidikan } \\
\text { tersebut. }\end{array}$ \\
\hline
\end{tabular}

Penelitian ini menggunakan tingkat tenaga kerja karena memiliki dampak positif terhadap pertumbuhan ekonomi sebagai input dalam menciptakan barang produksi. Berbeda dengan penelitian ini, Solomon (2011) menggunakan variabel tenaga kerja sebagai variabel moderasi terhadap hubungan antara PMA dengan pertumbuhan ekonomi karena tenaga kerja mampu menularkan teknologi yang dibawa oleh negara asing bagi negara yang dituju. Seperti penelitian tersebut, peneliti melakukan robustness test dari model penelitian yaitu dengan menggunakan variabel moderasi (influencing factor) terhadap variabel PMA dengan variabel TPT dimana TPT akan melemahkan hubungan antara PMA dan PDRB. Karena tren pertumbuhan penduduk Indonesia yang selalu meningkat maka TPT dapat menjadi ukuran yang baik dalam melihat banyaknya jumlah pekerja di Indonesia.

Variabel moderasi lain yang digunakan pada penelitian ini adalah IPM. Hal ini dikarenakan peningkatan pertumbuhan tersebut sangat bergantung kepada produktifitas pekerja bukan jenis investor (Wang \& Wang 2015). Penelitian ini menggunakan variabel PMDN untuk mengganti variabel PMA agar dapat memberikan bukti yang lebih beragam.

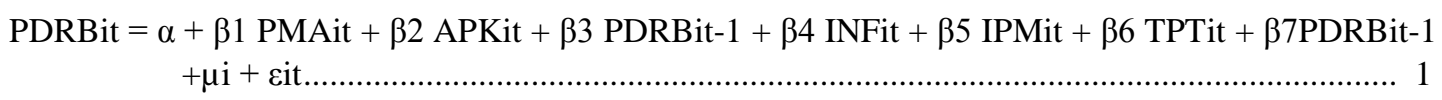




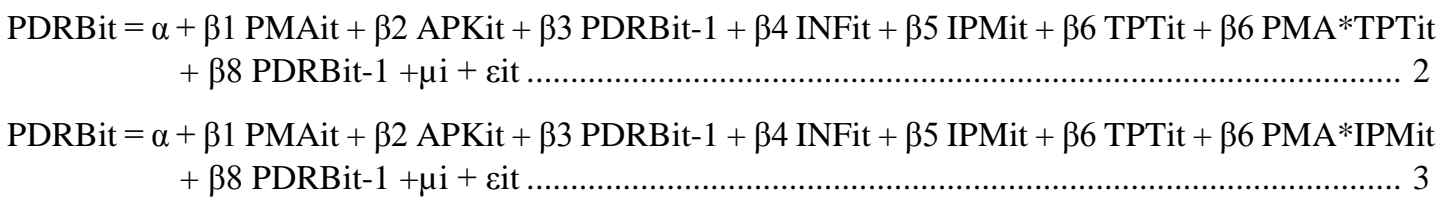

Keterangan :

PDRB $_{\text {it }} \quad$ : Produk Domestik Regional Bruto tahun sekarang

PMA $_{i t} \quad$ : Penanaman Modal Asing tahun sekarang

$\mathrm{PMDN}_{\mathrm{it}} \quad$ : Penanaman Modal Dalam Negeri tahun sekarang

APK $_{\text {it }} \quad$ : Angka Partisipasi Kasar tahun sekarang

PDRB $_{\text {it-1 }} \quad$ : Produk Domestik Regional Bruto tahun sebelumnya

$\mathrm{INF}_{\text {it }} \quad:$ Indeks Harga Konsumen tahun sekarang

IPM $_{\text {it }} \quad$ : Indeks Pembangunan Manusia tahun sekarang

$\mathrm{TPT}_{\text {it }} \quad$ : Tingkat Pengangguran Terbuka tahun sekarang

Penggunaan Ordinaty Least Square pada penelitian ini tidak tepat meskipun nilai error tidak saling berkorelasi karena model penelitian menggunakan variabel eksogen (variabel instrumen) yang merupakan lagged dari dependen variabel sehingga kedua variabel tersebut merupakan fungsi dari $\mu$. Dengan demikian, model penelitian ini diestimasi dengan menggunakan metode generalized method of moments (GMM) karena dapat memberikan estimasi yang baik dari efek jangka pendek dalam model. Selain itu GMM juga mampu menangkap potensi endogenitas dan autokorelasi. Namun, GMM memiliki kelemahan dalam memperlakukan efek lain di luar model yang memiliki kemungkinan besar untuk berkorelasi dengan variabel eksogen di dalam model (Nickell 1981).

\section{ANALISIS DAN PEMBAHASAN}

\section{Statistik Deskriptif}

Tabel 2 merangkum statistik deskriptif dan definisi variabel dari data yang digunakan pada penelitian ini. Secara rata-rata Produk Domestik Regional Bruto (PDRB) pada setiap provinsi pada rentang observasi tumbuh sebesar 15 persen dengan pertumbuhan tertinggi (76 persen) dan penurunan pertumbuhan tertinggi (-13 persen) terdapat pada provinsi Papua. Pertumbuhan tertinggi tersebut disebabkan oleh kenaikan produksi pada sub sektor penambangan tanpa migas (konsentrat tembaga) sedangkan penurunan disebabkan oleh jatuhnya jumlah ekspor. Jumlah PMA pada setiap provinsi bervariasi bahkan ada provinsi yang tidak memiliki arus PMA yaitu Aceh dan Bengkulu pada tahun tertentu. Adapun provinsi yang memiliki arus PMA yang tinggi setiap tahunnya adalah DKI Jakarta. 
Tabel 2

Statistik Deskriptif

\begin{tabular}{lrrrr}
\hline Variabel & \multicolumn{1}{c}{ Rata-rata } & \multicolumn{1}{c}{ Maksimum } & Minimum & Std. Deviasi \\
\hline PDRB & 0,15 & 0,76 & $-0,13$ & 0,07 \\
PMA & 24,05 & 32,20 & 0 & 8,92 \\
INF & 129,04 & 167,16 & 107,68 & 14,13 \\
IPM & 71,05 & 78,59 & 60,60 & 3,41 \\
TPT & 7,48 & 18,91 & 1,79 & 3,24 \\
APK & 63,40 & 90,04 & 37,92 & 11,11 \\
\hline
\end{tabular}

Sumber: data penelitian

Peningkatan harga barang konsumsi (INF) terbesar $(167,16)$ terjadi pada provinsi Maluku Utara sedangkan terendah $(107,68)$ terjadi pada provinsi Kepulauan Riau. Secara rata-rata 10 tahun, tidak terdapat pola khusus terkait karakteristik daerah seperti penduduk, geografis, iklim dan lainnya. Contohnya: meskipun Sumatera Selatan memiliki INF terbesar di Indonesia, namun provinsi tetangganya tidak ada yang menempati sepuluh terbesar. Provinsi dengan IPM terbesar di Indonesia adalah DKI Jakarta yang pada tahun 2013 memecahkan rekor IPM tertinggi di Indonesia yaitu 78,59 .

IPM terendah dimiliki oleh provinsi-provinsi di Nusa Tenggara dan Papua. Sebaliknya, pemerintah provinsi Bali mampu menciptakan lapangan pekerjaan yang banyak bagi penduduknya sehingga memiliki tingkat pengangguran terbuka yang sangat kecil pada tahun 2013 yaitu 1,79 persen. Sedangkan secara rata-rata 10 tahun, tingkat pengangguran terbesar dimiliki olah provinsi maju seperti DKI Jakarta, Jawa Barat dan Banten.

Provinsi DI Yogyakarta memiliki Angka Partisipasi Kasar (APK) terbesar pada tahun 2013 yang mencapai 90,04 persen sedangkan terendah adalah provinsi Gorontalo pada tahun 2004 yang mencapai 37,92 persen. Namun dalam empat tahun terakhir seluruh provinsi di Indonesia (kecuali Papua) memiliki tingkat APK lebih besar dari 50 persen. Meskipun APK di Indonesia mencapai 63,40 persen, namun angka tersebut termasuk rendah dibandingkan negara lain di dunia.

Dengan melihat Tabel 3 (Lampiran 1), secara rata-rata dari tahun 1990-2015, baik PMA dan PMDN, keduanya memiliki investasi terbesar pada industri makanan dan farmasi. Selain dari kedua industri tersebut, porsi PMA banyak ditempatkan pada industri yang membutuhkan investasi dan teknologi yang sangat besar dengan pengembalian yang lama seperti pertambangan, pengolahan logam dan elektronika. Sedangkan PMDN cukup banyak yang ditempatkan pada industri yang berhubungan dengan sumber daya alam yang dapat diperbaharui seperti listrik, air, kertas (olahan serbuk kayu) dan tanaman pangan. Selain itu, kelima terbesar industri PMDN memiliki permintaan yang besar dan relatif stabil sehingga harga komoditasnya tidak terlalu jatuh. Sebaliknya, pada PMA terutama industri pertambangan, pengolahan logam dan elektronika memiliki harga komoditas yang tidak stabil atau cenderung menurun. 
Hasil regresi pada Tabel 4 (Lampiran 1) penelitian Model 1 dan Model 3 menunjukkan bahwa tidak ada hubungan yang signifikan antara PMA dan PDRB. Hal ini mengindikasikan PMA hanya mengisi kekurangan modal yang tidak dapat ditutupi oleh PMDN. Di antara negara berkembang, PMA dapat meningkatkan pertumbuhan ekonomi pada negara yang menganut perekonomian terbuka dan memiliki penghasilan perkapita yang relatif besar (Sarkar 2007). Sebaliknya, PMDN mampu meningkatkan perekonomian di setiap provinsi, terlihat pada Tabel 4 model 4 yang dikarenakan sulitnya aturan investasi di Indonesia bagi pihak asing. Hal ini memperkuat dugaan bahwa investasi yang memiliki pengembalian yang besar (sektor strategis) diutamakan untuk diolah oleh penduduk domestik. Fenomena ini juga dapat mengindikasikan tidak adanya sinergi antara pihak asing dan dalam negeri dalam menjalankan bisnis di Indonesia (Ndikumana \& Verick 2008).

Berbeda dengan model lainnya, Model 2 membuktikan hubungan negatif antara PMA dan PDRB yang dikarenakan cukup banyak porsi PMA ditujukan pada industri yang tidak terlalu berkaitan dengan perekonomian domestik (Akinlo 2004). Selanjutnya, interaksi TPT menunjukkan tanda yang positif sehingga semakin besar pengangguran maka semakin memperkuat hubungan negatif antara PMA dan PDRB. Hal ini yang membuktikan dalam penelitian ini PMA dan PDRB memiliki hubungan negatif yang signifikan.

Pada keseluruhan model ditemukan bahwa PDRB pada tahun sebelumnya tidak mampu mempengaruhi atau memprediksi PDRB pada tahun berjalan. Hal ini wajar karena sampel penelitian adalah provinsi dalam suatu negara dimana setiap provinsi tidak memiliki hukum khusus yang dapat mencegah pelaku bisnis untuk keluar dari wilayahnya. Selain itu ada kecenderungan populasi di Indonesia terkonsentrasi di pulau Jawa sehingga penduduk provinsi di luar Jawa akan tertarik untuk beraktivitas di pulau Jawa.

Variabel kontrol IPM tidak memiliki hubungan yang signifikan terhadap PDRB termasuk hubungannya sebagai moderasi antara variabel PMA dan PDRB. IPM di Indonesia termasuk dalam kelas menengah urutan ke 108 dari 187 negara. Namun dengan membandingkan pada negara yang memiliki besaran perekonomian seperti Indonesia, IPM tersebut tergolong kecil. Selain itu penelitian ini menemukan hubungan positif antara TPT dan INF pada Model 2 dengan PDRB. Tingkat permintaan yang tinggi di Indonesia mampu mendorong pertumbuhan ekonomi di setiap provinsi, namun karena keterbatasan penawaran maka tidak jarang komoditas di Indonesia mengalami peningkatan harga (INF). Bentuk fase ekonomi Indonesia yang masih agraris menyebabkan kebutuhan akan pekerja lapangan yang besar. Hal ini mengakibatkan apabila masyarakat berpartisipasi dalam pendidikan maka perekonomian mereka kurang tumbuh. Riset memberi temuan bahwa ada hubungan negatif antara APK dan PDRB yang tidak terjadi di negara maju. 


\section{SIMPULAN, KETERBATASAN DAN SARAN}

\section{Simpulan}

Berdasarkan hasil analisis dibuktikan bahwa PMA tidak mampu meningkatkan pertumbuhan perekonomian regional karena pemerintah Indonesia memprioritaskan sektor strategis untuk dikelola dengan menggunakan PMDN. Hal ini diperkuat dengan kemampuan PMDN dalam meningkatkan perekonomian provinsi. Tidak seperti banyak penelitian sebelumnya, IPM tidak mampu berpengaruh terhadap perekonomian provinsi karena IPM di Indonesia tidak terlalu tinggi dibandingkan negara lainnya. Dengan demikian, pekerja di Indonesia tidak berkembang atau tidak terjadi transfer teknologi yang optimal.

Pemerintah perlu untuk mempertahankan PMDN dibandingkan PMA untuk meningkatkan perekonomian di setiap provinsi sehingga perekonomian Indonesia menjadi lebih merata. Dengan membandingkan hasil kesimpulan penelitian ini dan penelitian yang dilakukan Wang dan Wang (2015) terkait dampak akuisisi oleh pihak asing, PMA belum teruji dalam meningkatkan perekonomian disetiap provinsi. Sehingga pemerintah perlu mempertahankan investor asing namun hanya untuk mendorong investasi di sektor yang belum mampu diolah oleh pihak dalam negeri.

\section{Keterbatasan dan Saran}

Keterbatasan penelitian ini adalah kesulitan dalam pencarian data regional per provinsi sehingga penggunaan data kurang panjang. Keterbatasan lain dalam penelitian ini juga belum melihat dari segi infrastruktur, yang dilihat hanya panjang jalan dan sektor strategis, sedangkan masih banyak infrastruktur lain, antara lain, bandara, pelabuhan, rel kereta api, telepon, listrik dan lain lain. Penelitian ini tidak mampu mengukur multiplier effect dari PMA dan PMDN terhadap pertumbuhan ekonomi apabila diasumsikan mereka berinvestasi pada industri yang sama. Penelitian berikutnya diharapkan mampu menunjukkan pengaruh investasi dengan data infrastruktur yang lain seperti tingkat fertilitas, tingkat pendidikan dan modal manusia terhadap perekonomian jangka panjang.

\section{DAFTAR PUSTAKA}

Adams, Samuel, dan Eric Evans Osei Opoku. 2015. "Foreign direct investment, regulations and growth in sub-Saharan Africa." Economic Analysis and Policy 47 (C): 48-56. https://doi.org/10.1016/j.eap.2015.07.001.

Aizenman, Joshua, Yothin Jinjarak, dan Donghyun Park. 2013. "Capital Flows and Economic Growth in the Era of Financial Integration and Crisis, 1990-2010." Open Economies Review. https://doi.org/10.1007/s11079-012-9247-3.

Akinlo, A. Enisan. 2004. "Foreign direct investment and growth in Nigeria. An empirical investigation." Journal of Policy Modeling 26 (5): 627-39. 
https://doi.org/10.1016/j.jpolmod.2004.04.011.

Almfraji, Mohammad Amin, dan Mahmoud Khalid Almsafir. 2014. "Foreign Direct Investment and Economic Growth Literature Review from 1994 to 2012." Procedia - Social and Behavioral Sciences, 2014. https://doi.org/10.1016/j.sbspro.2014.03.668.

Feeny, Simon, Sasi Iamsiraroj, dan Mark McGillivray. 2014. "Growth and Foreign Direct Investment in the Pacific Island countries.” Economic Modelling, 2014. https://doi.org/10.1016/j.econmod.2013.11.018.

Gui-Diby, Steve Loris. 2014. "Impact of foreign direct investments on economic growth in Africa: Evidence from three decades of panel data analyses." $\begin{array}{llll}\text { Research in } 68 \text { (3): } & \text { 248-56. }\end{array}$ https://doi.org/10.1016/j.rie.2014.04.003.

Latip, Dedi. 2009. "Analisa pengaruh penanaman modal asing langsung (FDI) terhadap pertumbuhan ekonomi regional propinsi tahun 2000-2006."

Li, Xiaoying, dan Xiaming Liu. 2005. "Foreign Direct Investment and economic growth: An increasingly endogenous relationship." World Development 33 (3): 393-407. https://doi.org/10.1016/j.worlddev.2004.11.001.

Mello, L.R. De. 1999. "Foreign direct investment-led growth: evidence from time series and panel data." Oxford Economic Papers 51 (1): 133-51. https://doi.org/10.1093/oep/51.1.133.

Ndikumana, Léonce, dan Sher Verick. 2008. "The linkages between FDI and domestic investment: Unravelling the developmental impact of foreign investment in sub-Saharan Africa." Development Policy Review, 2008. https://doi.org/10.1111/j.1467-7679.2008.00430.x.

Nickell, Stephen. 1981. "Biases in Dynamic Models with Fixed Effects." Econometrica 49 (6): 1417-26. https://doi.org/10.2307/1911408.

Ostry, Jonathan D., Atish R. Ghosh, Karl Habermeier, Marcos Chamon, Mahvash S. Qureshi, dan Dennis B.S Reinhardt. 2010. "Capital inflows: The role of controls." International Monetary Fund, 2010.

Sarkar, Prabirjit. 2007. "Does Foreign Direct Investment Promote Growth? Panel data and Time Series Evidence from Less Developed Countries, 1970-2002." MPRA.

Solomon, E.M. 2011. "Foreign direct investment, host country factors and economic growth." Ensayos Revista de Economia 30 (1): 41-70.

Wang, Jian, dan Xiao Wang. 2015. "Benefits of foreign ownership: Evidence from foreign direct investment in China." Journal of International Economics 97 (2): 325-38. https://doi.org/10.1016/j.jinteco.2015.07.006. 


\section{LAMPIRAN 1}

Tabel 3

Lima Urutan Terbesar Industri berdasarkan PMDN dan PMA (rata-rata tahun 1990-2015)

\begin{tabular}{|c|c|c|c|c|c|}
\hline \multicolumn{3}{|c|}{ PMDN } & \multicolumn{3}{|c|}{ PMA } \\
\hline Industri & Porsi & Urutan & Industri & Porsi & Urutan \\
\hline Industri Makanan & $14 \%$ & 1 & Industri Makanan & $17 \%$ & 1 \\
\hline Listrik, Gas dan & & & Transportasi, & & \\
\hline Air & $11 \%$ & 2 & $\begin{array}{l}\text { Gudang dan } \\
\text { Telekomunikasi }\end{array}$ & $14 \%$ & 2 \\
\hline Industri Kimia & & & Industri Kimia & & \\
\hline $\begin{array}{l}\text { Dasar, Barang } \\
\text { Kimia dan } \\
\text { Farmasi }\end{array}$ & $9 \%$ & 3 & $\begin{array}{l}\text { Dasar, Barang } \\
\text { Kimia dan Farmasi }\end{array}$ & $11 \%$ & 3 \\
\hline $\begin{array}{l}\text { Industri Kertas, } \\
\text { Barang dari } \\
\text { kertas dan } \\
\text { Percetakan }\end{array}$ & $8 \%$ & 4 & $\begin{array}{l}\text { Industri Logam } \\
\text { Dasar, Barang } \\
\text { Logam, Mesin dan } \\
\text { Elektronik }\end{array}$ & $9 \%$ & 4 \\
\hline $\begin{array}{l}\text { Tanaman Pangan } \\
\text { dan Perkebunan }\end{array}$ & $8 \%$ & 5 & Pertambangan & $7 \%$ & 5 \\
\hline
\end{tabular}

Tabel 4

Ringkasan Hasil Regresi

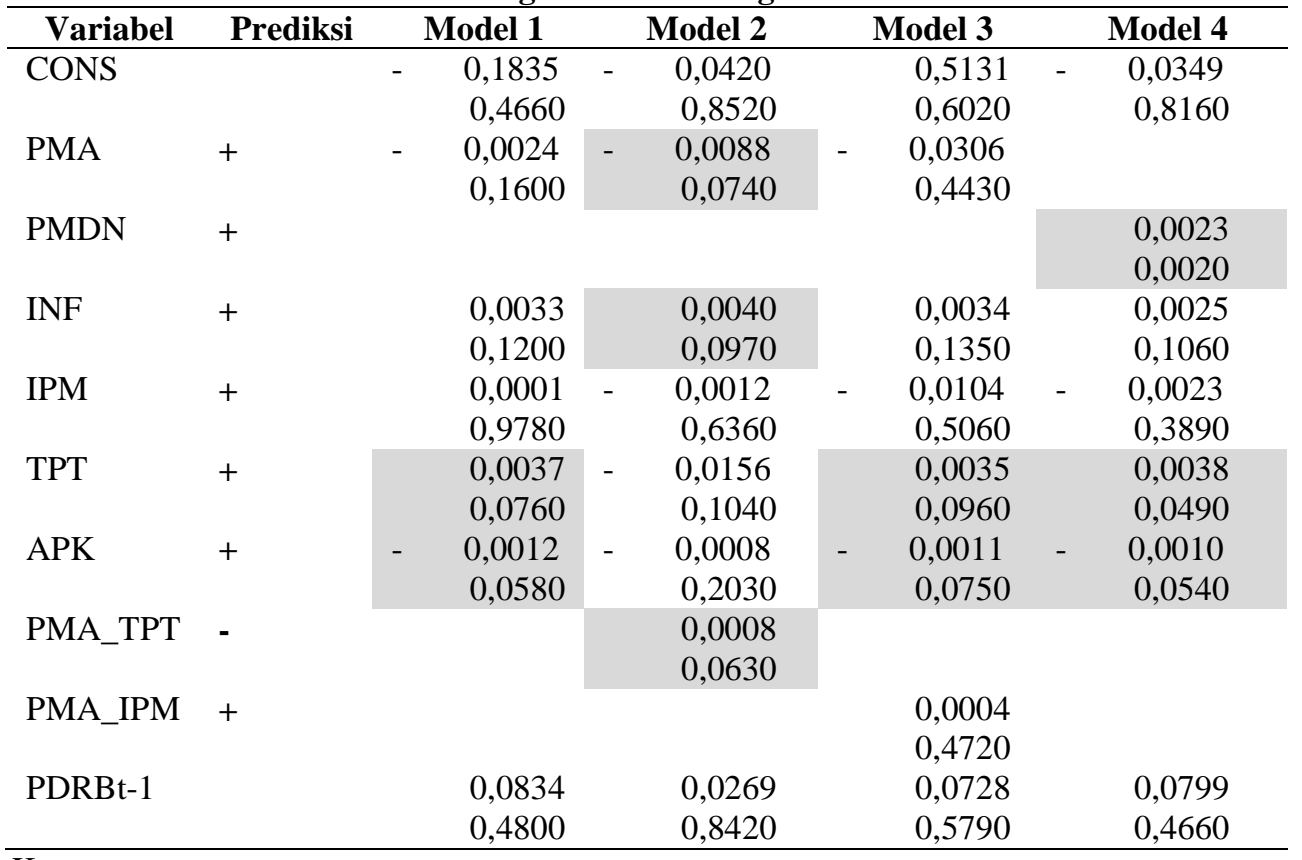

Keterangan :

Hubungan yang signifikan pada alpha $=1$ persen, 5 persen, atau 10 persen

Model 1 : Model dasar penelitian yaitu melihat hubungan antar variable PMA terhadap PDRB

Model 2 : Pengembangan dari Model 1 dengan menggunakan variabel moderasi TPT terhadap hubungan antara PMA dan PDRB (robustness test)

Model 3 : Pengembangan dari Model 1 dengan menggunakan variabel moderasi IPM terhadap hubungan antara PMA dan PDRB (robustness test)

Model 4 : Pengembangan dari Model 1 dengan menggunakan variabel dependen PMDN yang menggantikan PMA (robustness test) 


\section{LAMPIRAN 2}

Tabel 5

Daftar Provinsi Sampel dan Nilai Rata-Rata Indikator Tahun 2004-2014

\begin{tabular}{|c|c|c|c|c|c|c|c|c|c|c|}
\hline \multirow[t]{2}{*}{ Provinsi } & \multicolumn{2}{|c|}{$\begin{array}{c}\text { Pertumbuhan } \\
\text { PDRB }\end{array}$} & \multicolumn{2}{|c|}{$\begin{array}{c}\text { PMA } \\
\text { (juta US\$) }\end{array}$} & \multicolumn{2}{|c|}{$\begin{array}{c}\text { PMDN } \\
\text { (milyar Rp) }\end{array}$} & \multicolumn{2}{|c|}{ TPT (\%) } & \multicolumn{2}{|c|}{$\begin{array}{c}\text { IPM } \\
\text { (maks. 100) }\end{array}$} \\
\hline & $\mathrm{N}$ & $\mathrm{R}$ & $\mathrm{N}$ & $\mathrm{R}$ & $\mathrm{N}$ & $\mathrm{R}$ & $\mathrm{N}$ & $\mathrm{R}$ & $\mathrm{N}$ & $\mathrm{R}$ \\
\hline Aceh & $8,3 \%$ & 31 & 32 & 25 & 380 & 19 & $9,5 \%$ & 8 & 70,5 & 17 \\
\hline Sumatera Utara & $14,7 \%$ & 13 & 293 & 8 & 1,509 & 10 & $9,0 \%$ & 12 & 73,1 & 8 \\
\hline Sumatera Barat & $14,1 \%$ & 17 & 42 & 22 & 342 & 20 & $9,1 \%$ & 11 & 72,5 & 9 \\
\hline Riau & $17,9 \%$ & 3 & 560 & 6 & 3,659 & 5 & $9,1 \%$ & 10 & 74,6 & 4 \\
\hline Jambi & $18,0 \%$ & 2 & 41 & 23 & 1,261 & 11 & $5,6 \%$ & 27 & 71,8 & 10 \\
\hline Sumatera Selatan & $15,2 \%$ & 11 & 261 & 9 & 1,127 & 13 & $7,6 \%$ & 13 & 71,6 & 12 \\
\hline Bengkulu & $14,4 \%$ & 16 & 13 & 28 & 16 & 31 & $5,1 \%$ & 29 & 71,8 & 11 \\
\hline Lampung & $17,1 \%$ & 4 & 64 & 20 & 535 & 16 & $6,9 \%$ & 18 & 70,2 & 19 \\
\hline Kep. Bangka Belitung & $14,8 \%$ & 12 & 40 & 24 & 252 & 23 & $6,1 \%$ & 24 & 71,6 & 13 \\
\hline Kepulauan Riau & $5,1 \%$ & 33 & 168 & 15 & 222 & 24 & $9,4 \%$ & 9 & 73,7 & 6 \\
\hline DKI Jakarta & $13,9 \%$ & 19 & 4,222 & 1 & 5,244 & 3 & $12,1 \%$ & 2 & 77,0 & 1 \\
\hline Jawa Barat & $14,6 \%$ & 15 & 2,659 & 2 & 7,436 & 2 & $11,8 \%$ & 3 & 70,9 & 16 \\
\hline Jawa Tengah & $13,8 \%$ & 20 & 161 & 17 & 2,563 & 7 & $7,0 \%$ & 16 & 71,2 & 14 \\
\hline DI Yogyakarta & $12,5 \%$ & 26 & 20 & 26 & 69 & 28 & $5,2 \%$ & 28 & 74,7 & 3 \\
\hline Jawa Timur & $14,0 \%$ & 18 & 1,164 & 4 & 8,142 & 1 & $6,2 \%$ & 23 & 70,0 & 21 \\
\hline Banten & $12,0 \%$ & 30 & 1,433 & 3 & 3,395 & 6 & $14,0 \%$ & 1 & 69,7 & 23 \\
\hline Bali & $13,0 \%$ & 25 & 203 & 11 & 638 & 15 & $3,6 \%$ & 33 & 71,1 & 15 \\
\hline Nusa Tenggara Barat & $12,2 \%$ & 28 & 167 & 16 & 311 & 22 & $6,5 \%$ & 19 & 63,9 & 32 \\
\hline Nusa Tenggara Timur & $13,2 \%$ & 22 & 4 & 33 & 15 & 32 & $3,7 \%$ & 32 & 65,6 & 31 \\
\hline Kalimantan Barat & $12,2 \%$ & 29 & 169 & 14 & 839 & 14 & $5,9 \%$ & 25 & 67,8 & 29 \\
\hline Kalimantan Tengah & $14,6 \%$ & 14 & 219 & 10 & 1,630 & 9 & $4,7 \%$ & 31 & 73,6 & 7 \\
\hline Kalimantan Selatan & $12,4 \%$ & 27 & 122 & 18 & 1,791 & 8 & $6,2 \%$ & 22 & 68,7 & 26 \\
\hline Kalimantan Timur & $15,6 \%$ & 8 & 563 & 5 & 3,674 & 4 & $10,3 \%$ & 7 & 74,3 & 5 \\
\hline Sulawesi Utara & $13,6 \%$ & 21 & 63 & 21 & 176 & 26 & $10,6 \%$ & 5 & 75,1 & 2 \\
\hline Sulawesi Tengah & $15,5 \%$ & 9 & 198 & 12 & 412 & 18 & $5,9 \%$ & 26 & 69,7 & 22 \\
\hline Sulawesi Selatan & $16,3 \%$ & 6 & 189 & 13 & 1,204 & 12 & $10,4 \%$ & 6 & 70,0 & 20 \\
\hline Sulawesi Tenggara & $16,0 \%$ & 7 & 14 & 27 & 456 & 17 & $6,5 \%$ & 20 & 68,8 & 25 \\
\hline Gorontalo & $16,8 \%$ & 5 & 12 & 30 & 49 & 29 & $7,0 \%$ & 17 & 68,8 & 24 \\
\hline Sulawesi Barat & $7,0 \%$ & 32 & 4 & 32 & 188 & 25 & $7,1 \%$ & 15 & 68,2 & 28 \\
\hline Maluku & $13,0 \%$ & 23 & 10 & 31 & 1 & 33 & $10,8 \%$ & 4 & 70,4 & 18 \\
\hline Maluku Utara & $13,0 \%$ & 24 & 67 & 19 & 132 & 27 & $6,4 \%$ & 21 & 68,2 & 27 \\
\hline Papua Barat & $24,4 \%$ & 1 & 13 & 29 & 41 & 30 & $7,5 \%$ & 14 & 67,1 & 30 \\
\hline Papua & $15,5 \%$ & 10 & 475 & 7 & 314 & 21 & $5,0 \%$ & 30 & 63,7 & 33 \\
\hline
\end{tabular}

Keterangan: $\mathrm{N}$ adalah angka nominal, $\mathrm{R}$ andalah peringkat dari yang terbesar ke terkecil. 